\title{
ABORDAGEM DOS GÊNEROS NO ENSINO DE LÍNGUAS
}

\author{
Eliane Gouvêa Lousada*
}

Universidade de São Paulo, São Paulo, SP, Brasil

Maria Inês Batista Campos**

Universidade de São Paulo, São Paulo, SP, Brasil

A questão dos gêneros textuais/discursivos chega ao Brasil na década de 90 e, em pouco tempo, começa a exercer influência no ensino de língua materna, ao ter seus princípios incorporados em documentos oficiais, tais como os $\mathrm{PCN}$ (Parâmetros Curriculares Nacionais), em nível nacional, e em outros documentos da esfera estadual. Assim, a problemática dos gêneros acaba entrando na escola, seja pelas iniciativas de formação de professores para o ensino por meio de gêneros, seja pelo livro didático que, ao adequar-se ao PNLD (Programa Nacional do Livro Didático), passa a considerar os gêneros como unidades de ensino.

Ao propor uma compreensão inovadora do ensino da leitura e da escrita e, assim, orientar de forma diferente o ensino de línguas, essa adoção dos gêneros para o ensino não se faz sem conflitos no âmbito das políticas públicas, da elaboração de material didático e, sobretudo, do trabalho dos professores. Das políticas públicas, nascem imposições que têm dificuldade em penetrar no terreno da prática escolar. No que diz respeito à elaboração de livros didáticos, vemos as tensões entre editores, autores e avaliadores, que deixam rastros materializados nas contradições existentes nas diversas coleções didáticas. Em relação ao trabalho dos professores, constatamos a dificuldade deles em adequar suas práticas de ensino, as necessidades dos alunos e as imposições da escola. Há quase duas décadas da chegada dos gêneros na escola brasileira, muitas pesquisas têm se concentrado em investigar as consequências dessas orientações para o ensino em âmbito nacional.

Neste número 28, volume 2 de 2015, Linha d'Água traz aos leitores algumas questões frequentes que permeiam o ensino de língua materna, isto é, a problemática dos gêneros, os gêneros no livro didático e o trabalho do professor com os gêneros. Esses temas finalizam com artigos que vieram de instituições nacionais e estrangeiras, mostrando o compromisso dos professores e pesquisadores que desenvolvem trabalhos na área. Participaram deste número dezenove autores de

* Professora doutora da Universidade de São Paulo, Brasil.

* Professora doutora da Universidade de São Paulo, Brasil; maricamp@usp.br. 
vários estados brasileiros como Paraná, São Paulo, Paraíba, Piauí, Rio Grande do Norte e das universidades francesas - Paris-Sorbonne, Paris 8, Grenoble e finalmente da Universidade de Geneve, Suíça.

Dando início à discussão sobre o papel dos gêneros textuais na didática das línguas, o artigo de Joaquim Dolz e Myriam Abouzaid aborda algumas questões fundamentais para esse campo de estudos, como, por exemplo, o trabalho concomitante com os traços familiares dos gêneros e com as características específicas dos textos. Ao tratar da avaliação dos gêneros em uma perspectiva didática, os autores mostram a diversidade das práticas de ensino e as dificuldades dos professores em trabalhar as características genéricas e as produções textuais singulares produzidas pelos alunos.

Com a preocupação de pensar no papel das novas linguagens no ensino da língua portuguesa, Miriam Bauab Puzzo e Sonia Sueli Berti-Santos propõem uma discussão sobre a linguagem verbo-visual de uma reportagem impressa, visando a refletir sobre os efeitos de sentido provocados pelas relações dialógicas que atravessam os enunciados. As autoras analisam as estratégias de leitura de reportagens que enfatizam a observação da linguagem verbo-visual e de seus efeitos na construção de sentido em gêneros da mídia.

Procurando investigar o trabalho com gêneros textuais proposto em um livro didático para o ensino de língua portuguesa no Ensino Fundamental II, o artigo de João Bosco Figueiredo-Gomes e Arisberto Gomes de Souza se propõe a verificar se a coleção traz uma oportunidade de compreensão dos gêneros em relação ao seu contexto de uso social, para o aluno e em relação à escolha de coleções didáticas, para o professor. A análise apresentada tem o objetivo de fornecer parâmetros para a escolha de coleções didáticas e para implementações pedagógicas, podendo ser vista como um auxílio para os professores.

Também tratando da análise de livros didáticos, o artigo de Bárbara Olímpia Ramos de Melo traz uma análise de dois livros didáticos de língua portuguesa, com o intuito de estudar a proposta de ensino do gênero artigo de opinião nos livros selecionados. Propondo uma pesquisa bibliográfica de cunho analítico, a autora conclui que há, em ambos materiais didáticos, poucas propostas com gêneros da esfera do argumentar, embora um dos livros didáticos adote uma abordagem mais adequada para o ensino desses gêneros. A autora conclui ressaltando a importância de se levar em conta a complexidade das relações de aprendizagem, nas quais não apenas os livros didáticos, mas também o professor e os alunos, exercem sua influência.

Com foco nos livros didáticos de língua portuguesa para o ensino médio aprovados nos guias de escolha do livro didático do PNLD de 2011 e 2014, Terezinha 
da Conceição Costa-Hübes e Leliane Regina Ortega Esteves procuram investigar como se dá a configuração do gênero regras de jogo nas coleções analisadas. As autoras apresentam um levantamento desse gênero nos livros didáticos analisados, considerados por elas como o principal material de apoio do professor.

O artigo de Sylvie Plane e Kathy Similowski visa a discutir o papel dos livros didáticos na aprendizagem da redação na escola francesa, cujo ensino oficial começa em 1880. Para tanto, as autoras analisam três livros didáticos publicados em décadas diferentes procurando compreender como esses livros revelam diferentes influências sociais e ideológicas, informando sobre as interrogações que se coloca a comunidade educativa sobre os saberes, os modos de ensino e aprendizagem e as finalidades da escola.

Voltando-se para o ensino de língua portuguesa com vistas à formação profissional, Ana Lúcia Tinoco Cabral apresenta uma reflexão sobre a proficiência escritora dos estudantes de Direito que, dada importância da língua escrita para essa profissão, se torna, para eles, uma ferramenta de trabalho. Para tanto, a autora aborda o estatuto das sequências textuais narrativas e da construção argumentativa no gênero petição inicial, apontando diretrizes para o trabalho com esse gênero na universidade.

Ao ressaltar a importância do fazer docente no trabalho com os gêneros textuais, o artigo de Linduarte Pereira Rodrigues e Maria Aparecida Calado de Oliveira Dantas investiga o tratamento da oralidade que é preconizado nos documentos oficiais, como os PCN de Língua Portuguesa, como uma forma de proporcionar uma avaliação cuidadosa dos livros didáticos a serem adotados nas escolas. Paralelamente, as autoras procuram discutir a modalidade oral da língua como objeto de ensino, focalizando as ações docentes que são propostas para esse trabalho.

Preocupadas com o trabalho do professor ao implementar uma sequência didática para trabalhar um gênero textual em sala de aula, Cláudia L. N.Saito, Daniela da Silva e Elvira Lopes Nascimento têm por objetivo compreender como as ações trabalhadas nos cursos de formação continuada de professores de Língua Portuguesa são interpretadas e colocadas em prática pelos docentes. Para atingir seus objetivos, as autoras analisam dados empíricos de uma professora que coloca em prática o que aprendeu na formação continuada sobre o ensino de gêneros, procurando mostrar as tensões entre atividades impedidas, os fatores próprios da situação de trabalho e o desenvolvimento do poder de agir dessa professora.

Finalizando os artigos deste número, Miriam B. Puzzo aborda a questão da autoria e do estilo do ponto de vista do conceito de gêneros discursivos, tal como proposto por Bakthin (2003). Tomando por base um artigo de opinião publicado 
Linha D'Água (Online), São Paulo, v. 28, n. 2, p. 1-4, dez 2015

em um jornal brasileiro, a autora procura mostrar que o estilo não é individual, mas dialógico, criando formas expressivas diferenciadas.

O número traz ainda três resenhas de obras recentes que abordam o ensino de línguas. A primeira, realizada por Simone Dantas-Longhi, apresenta a relevante obra de Nascimento e Rojo, publicada em 2014 e que sintetiza as pesquisas realizadas pelos membros do GT de gêneros textuais/discursivos da ANPOLL.A segunda, de autoria de Flavia Fazion, traz a publicação inovadora de Lousada e Bronckart, publicada em 2015, sobre o ensino de línguas, materna e estrangeiras, baseado em gêneros textuais. Para finalizar, Fumo e Carreira apresentam uma resenha da obra de Cavalcante, Custódio e Brito, publicada em 2014, que investiga o processo de produção textual e sua contribuição para o ensino de línguas.

Gostaríamos de agradecer às tradutoras do artigo para o português e à revisão cuidadosa, permitindo a qualidade do texto. Agradecemos também o auxílio que recebemos do SIBi, Sistema integrado das Bibliotecas da Universidade de São Paulo, especialmente, por meio do Plano de Incentivo à Publicação de Periódicos da USP-2014, acreditando na produtividade científica de Linha d'Água e no intercâmbio de conhecimento entre pesquisadores e professores do ensino básico. 